\title{
Effects of C/N Ratio on Water Quality, Growth Performance, Digestive Enzyme Activity and Antioxidant Status of Nile Tilapia Oreochromis niloticus (Linnaeus, 1758) in Biofloc Based Culture System
}

\author{
Ammar Dilmi $^{1,2, *} \mathbb{D}$, Wahid Refes $^{1}\left(\mathbb{D}\right.$, Abdellah Meknachi $^{2}(\mathbb{C})$
}

\begin{abstract}
${ }^{1}$ Ecole Nationale Supérieure des Sciences de la Mer et de l'Aménagement du Littoral (ENSSMAL), Campus Universitaire de Dely Ibrahim, Bois des cars, Dely Ibrahim 16320, Alger, Algeria.

${ }^{2}$ Centre National de Recherche et du Développement de la Pêche et de l'Aquaculture (CNRDPA), Bd Colonel Amirouche Bou-Ismail, Algeria.
\end{abstract}

\section{How to cite}

Dilmi, A., Refes, W., Meknachi, A. (2022). Effects of C/N Ratio on Water Quality, Growth Performance, Digestive Enzyme Activity and Antioxidant Status of Nile tilapia Oreochromis niloticus (Linnaeus, 1758) in Biofloc Based Culture System. Turkish Journal of Fisheries and Aquatic Sciences, 22(1), TRJFAS19754. http://doi.org/10.4194/TRJFAS19754

\section{Article History}

Received 25 April 2021

Accepted 06 September 2021

First Online 08 September 2021

\section{Corresponding Author}

Tel.: +213697641708

E-mail: dilmi80@gmail.com

\section{Keywords}

Biofloc technology

Nutrition

Tilapiculture

Water recirculation

\begin{abstract}
A 62-d trial was conducted to evaluate the effects of different $\mathrm{C} / \mathrm{N}$ ratios on water quality, growth performance, digestives activity, and antioxidant indicators of tilapia fingerlings in BFT systems. Three biofloc treatments (added molasses) with a $\mathrm{C} / \mathrm{N}$ ratio of 14 (BFT14), 17 (BFT17), and 20 (BFT20) were tested against control in clear-water, each treatment in triplicate. Four hundred twenty tilapias $(24.2 \pm 0.1 \mathrm{~g})$ were distributed on 12 tanks of $350 \mathrm{~L}$. The dynamics of water quality parameters showed a shift from a predominantly autotrophic to a predominantly heterotrophic biofloc with an increase in the $\mathrm{C} / \mathrm{N}$ ratio from 14 to 20 . The growth and Feed conversion of tilapia were not significantly different between the control, BFT14, and BFT17 groups. A low weight gain and high FCR were found in the BFT20 treatment $(0.61 \pm 0.07$ and $1.11 \pm 0.12$ $\mathrm{g} / \mathrm{d})$ compared to the control $(0.84 \pm 0.05$ and $1 \pm 0.07 \mathrm{~g} / \mathrm{d})$. Activities of proteases and alpha-amylase in the liver and digestive tract were similar in all treatments. As a measure of stress, CAT and SOD activities did not differ significantly among the four groups. Overall, it was possible to reduce the $\mathrm{C} / \mathrm{N}$ ratio to 14 , without negatively affecting the biofloc development, growth performance, and physiological parameters of juvenile tilapia.
\end{abstract}

\section{Introduction}

Algeria has drafted an ambitious program for the development of inland aquaculture, with the creation of aquaculture farms for warm-water fish like tilapias and catfish MPRH (2014). The southern regions of Algeria have significant groundwater resources that can be used in aquaculture. However, the most important part of this resource is constituted by non-renewable fossil aquifers (Saker \& Bouhoun, 2007) and its exploitation requires rational and judicious management for sustainable aquaculture development. Conventional open-water fish farms require a significant renewal of water for the elimination of wastes generated by cultured fish. However, large quantities of waste are released directly to the external environment, which is further amplified by the global trend of intensification of production (Edwards, 2015). Minimizing water exchange in aquaculture improves biosecurity by reducing pollution and limiting the risk of disease propagation (Khanjani \& Sharifinia, 2020).

Aquaculture wastewater comes in the forms of suspended wastes (uneaten feed and fecal matter) and dissolved wastes (ammonia, nitrite, nitrate, phosphorus, and organic matter) (Miller \& Semmens, 2002). Conventional wastes management in aquaculture systems is based on effluent treatment outside the culture unit, using settling ponds and wetlands, or a combination of mechanical and biological filtration by nitrifying bacteria (Crab et al., 2012; Tucker et al., 2008). 
These techniques generate additional production costs and require frequent maintenance (Crab et al., 2012). The biofloc technology (BFT) is an eco-friendly aquaculture method, based on a waste nutrients treatment within the culture unit and requires a low water renewal rate (0.5 to $1 \%$ per day) (Hargreaves, 2013; Singh et al., 2020). The main principle of BFT consists of the addition of external carbon sources combined with high aeration to promote the development of suspended microbial aggregates in the culture system (Ahmad et al., 2017; Bossier \& Ekasari, 2017; Khanjani \& Sharifinia, 2020), which contains a various mixture of bacteria, microalgae, zooplankton and organic particles (Cardona et al., 2016; Dauda, 2020). Bacterial populations play a key role in water quality control through the removal of nitrogenous wastes (Dauda, 2020). Furthermore, the biofloc can be used as a food source for aquaculture species such as shrimp and tilapia (Crab et al., 2012; Khanjani \& Sharifinia, 2020).

Several studies have reported the beneficial effect of the biofloc environment in fish and shrimp culture, notably the improvement of water quality (Minabi et al., 2020; Rajkumar et al., 2016; Wang et al., 2015), enhancing growth performance and feed utilization (Azhar et al., 2020; Hisano et al., 2019; Kamilya et al., 2017; Luo et al., 2014) and improving aquatic animal welfare (Chakrapani et al., 2021; Liu et al., 2018; Yu et al., 2020).

In all aquatic animal production systems, the main objective of water quality management is to maintain nitrogen waste concentrations less than toxic levels (Hargreaves, 2013), which are variable depending on the species and development stage.

In the biofloc system, ammonia removal is achieved by the combined action of microalgae, autotrophic bacteria, and heterotrophic bacteria whose dominance is mainly determined by the carbon/nitrogen $(\mathrm{C} / \mathrm{N})$ ratio in the culture water (Ebeling et al., 2006; Hargreaves, 2006; Xu et al., 2016). The increase in the $\mathrm{C} / \mathrm{N}$ ratio leads to a shift from a biofloc environment dominated by photoautotrophic or chemoautotrophic communities to an environment dominated by heterotrophic communities, with impacts on water quality and floc production (Liu et al., 2018; Xu et al., 2016). Generally, feeds commonly used in aquaculture have a $\mathrm{C} / \mathrm{N}$ ratio of around 10 . However, it is necessary to increase the $\mathrm{C} / \mathrm{N}$ ratio by adding an external carbon source to promote biofloc development (Hargreaves, 2013). Carbohydrate additions favor suspended solids accumulation by increasing the bacterial biomass production in the heterotrophic system (Gaona et al., 2016; Gou et al., 2019), which can clog the gills of fish and shrimp at high concentrations. The $\mathrm{C} / \mathrm{N}$ ratio should be optimized to ensure biofloc formation while limiting the excessive accumulation of suspended solids. Crab et al. (2009), suggest that the $\mathrm{C} / \mathrm{N}$ ratio should be maintained around 20 to neutralize the inorganic nitrogen. whereas, $\mathrm{Xu}$ et al. (2016) reported that the $\mathrm{C} / \mathrm{N}$ ratio can be reduced to 12 in shrimp culture by promoting the autotrophic pathway of ammonium removal. Tilapia is the second most important cultured fish in word after the carps. This species has the advantages of fast growth speed, adaptability to high stocking densities, strong resistance to diseases, adaptable feeding habits, and tolerance of poor water quality (Prabu et al., 2019). Tilapia is perfectly adapted to biofloc systems, by its ability to consume biofloc, as well as its tolerance to high concentrations of suspended solids (Avnimelech, 2011; Poli et al., 2019).

Previous studies have reported the improvement of growth parameters, feed efficiency, enzyme activity, and immune response of tilapia in the BFT system (Haraz et al., 2018; Liu et al., 2018; Long et al., 2015; Mirzakhani et al., 2019). The impact of $\mathrm{C} / \mathrm{N}$ ratio manipulation on the evolution of physicochemical parameters and its relationship to the physiological indices such as digestive enzyme activity and antioxidant capacity of tilapia remains poorly documented.

Therefore, the present study aims to investigate the effect of varying the $\mathrm{C} / \mathrm{N}$ ratio between 14 and 20 on water quality, growth performance, digestive enzyme activity, and antioxidant status of tilapia in the BFT system.

\section{Materials and Methods}

\section{Experimental Design and Fish Stocking}

The experiment was conducted over 62 days, from December 2017 to February 2018, at the marine experimental fish farm of the National Center for Research and Development of Fisheries and Aquaculture located at Bou Ismail, $50 \mathrm{~km}$ at the West of Algiers (Algeria). Four hundred twenty mixed-sex tilapia with an average weight of $24.2 \pm 0.1 \mathrm{~g}$, were distributed in 12 conical tanks ( $0.8 \mathrm{~m}$ diameter) with a useful volume of 350 liters. The placement of the tanks followed a completely randomized design, with four treatments in three replicates. This experiment consisted of three treatments in BFT systems at $\mathrm{C} / \mathrm{N}$ ratios of 14 (BFT14), 17 (BFT17), and 20 (BFT20), compared to the control group (C) in clear water. To accelerate the initial development of biofloc in the new culture system, the BFT tanks were filled to $50 \%$ with biofloc-rich water as suggested by Krummenauer et al. (2014). The biofloc-rich water was taken from a $3 \mathrm{~m}^{3}$ tank of tilapia culture with a stabilized biofloc water, which had concentrations of $0.3 \mathrm{mg} / \mathrm{L}$ ammonium, 0.12 $\mathrm{mg} / \mathrm{L}$ nitrite, $150 \mathrm{mg} / \mathrm{L}$ nitrates, $455 \mathrm{mg} / \mathrm{L}$ total suspended solids, and alkalinity of $160 \mathrm{mg} / \mathrm{L}$. The tanks were placed in a greenhouse under a natural photoperiod. Each tank was equipped with an electric thermostat $(500 \mathrm{~W})$ to maintain the water temperature at $24^{\circ} \mathrm{C}$ and two air stones to provide water oxygenation and agitation. Nets were installed above the tanks to prevent the escape of fish. The BFT group treatments 
were conducted without water exchange, except to compensate for losses by evaporation.

In the control tanks, water is renewed 05 to 08 times a day from a $16 \mathrm{~m}^{3}$ reservoir tank. The fish were fed to satiety, three times daily with a commercial pellet of $02 \mathrm{~mm}$ for the first 30 days (45\% protein, $12 \%$ fat, 2.4 $\%$ fiber, $8.8 \%$ ash), then with a $3 \mathrm{~mm}$ pellet $(30 \%$ protein, $6 \%$ fat, $3.4 \%$ fiber, $8.2 \%$ ash) until the end of the experiment. The quantities of food distributed each day were noted in the daily tracking sheets. In biofloc groups, molasses is added daily as a carbon source to adjust $\mathrm{C} / \mathrm{N}$ ratios. The amounts of molasses used were calculated taking into account the carbon content in the feed and molasses, according to Duy and Van Khanh (2018).

\section{Water Quality Parameters}

Water temperature $(\mathrm{T})$ and dissolved oxygen (DO) were monitored twice daily by using a handheld Oximeter (YSI 85). The $\mathrm{pH}$ was measured daily by a handheld $\mathrm{pH}$ meter (HANNA HI9025). Ammonium $\left(\mathrm{NH}_{4}^{+}\right)$, Nitrite $\left(\mathrm{NO}_{2}^{-}\right)$, and Alkalinity (ALK) were monitored twice a week. The determination of total suspended solids (TSS) is carried out weekly. Analyses of $\mathrm{NH}_{4}{ }^{+}, \mathrm{NO}_{2}{ }^{-}$and $\mathrm{ALK}$ were carried out according to Rodier et al. (2009). Nitrates $\left(\mathrm{NO}_{3}{ }^{-}\right)$are measured once a week with a test strip (MQuant 1100200001). The settleable solids (SS) were measured twice a week by sedimentation of 1 liter of the sample in an Imhoff cone for 20 minutes (Avnimelech \& Kochba, 2009).

\section{Growth and Production Parameters}

After 30 days experiment (D30) and at the end of a feeding trial (D62), all the fish in each tank were counted and weighed to calculate the zootechnical parameters according to the following equations (Kamilya et al., 2017; Zhang et al., 2016):

Survival rate:

$$
S(\%)=N_{f} / N_{i} \times 100
$$

Daily weight gain:

$$
\text { DWG }(g / d)=\left(I B W_{f}-\mid B W_{i}\right) / t
$$

Specific growth rate:

$$
\text { SGR }(\% / d)=\left(\ln I B W_{f}-\ln I B W_{i}\right) / t \times 100
$$

Feed conversion ratio:

FCR $=$ Total feed supply $(\mathrm{kg}) /$ fish biomass increase $(\mathrm{kg})$

Final stocking density:

$$
\text { FSD }\left(\mathrm{kg} / \mathrm{m}^{3}\right)=\text { Final biomass }(\mathrm{kg}) / \text { tank volume }\left(\mathrm{m}^{3}\right)
$$

Where $\mathrm{N}_{\mathrm{f}}$ is the final number of fish, $\mathrm{N}_{i}$ is the initial number of fish, IBW $\mathrm{I}_{\mathrm{f}}$ is the final body weight, $\mathrm{IBW}_{\mathrm{i}}$ is the initial body weight and $t$ is the time in days.

\section{Tissue Sampling and Preparation}

At the end of the feeding trial, fish were starved for $24 \mathrm{~h}$ prior to sampling. Four random fish from each tank were euthanized in 0.2\% 2-phenoxy-ethanol (van der Salm et al., 2005) for desiccation to remove the digestive tract and liver. Afterward, the two organs were homogenized separately on ice with 10 volumes of Tris$\mathrm{HCl}$ buffer $(\mathrm{pH} 7.5)$ using a blender. The mixtures were centrifuged at $6000 \mathrm{rpm}$ for $60 \mathrm{~min}$ at $4{ }^{\circ} \mathrm{C}$ in a refrigerated centrifuge and the supernatants were stored at $-80{ }^{\circ} \mathrm{C}$ until utilization. The analysis was performed by two replicates for each sample.

\section{Proteases Activity}

Proteases were determined according to the method described by Anasori et al. (2015), using casein as a substrate. One $\mathrm{ml}$ of the sample was added to $1 \mathrm{ml}$ of $1 \%$ casein solution and incubated at $37^{\circ} \mathrm{C}$ for $10 \mathrm{~min}$, then the trichloroacetic acid (TCA) was added to stop the reaction. After standing for $30 \mathrm{~min}$ at room temperature, the mixture was centrifuged for $05 \mathrm{~min}$ at $9000 \mathrm{rpm}$. The supernatant was mixed with the sodium carbonate solution and the Folin-Ciocalteu reagent, then incubated for $30 \mathrm{~min}$ in the dark. The solution was centrifuged for 05 minutes at $9000 \mathrm{rpm}$ and the absorbance of their supernatants was measured at 660 $\mathrm{nm}$. Protease activity was determined by reference to a calibration curve using tyrosine as the standard. One unit $(U)$ of protease activity is defined as the amount of enzyme required to release one micromole of tyrosine per minute (Hatate et al., 2000).

\section{Amylase Activity}

The alpha-amylase activity was determined according to Bernfeld (1955) using starch as a substrate. The reaction mixture consists of $0.5 \mathrm{ml}$ of $1 \%$ starch solution and $0.5 \mathrm{ml}$ of the sample diluted in phosphate buffer ( $\mathrm{pH}$ 6.9). After incubation for 3 minutes at $25^{\circ} \mathrm{C}$, the reaction is stopped by the addition of a dinitrosalicylic acid reagent. The solution tubes were placed in a boiling water bath for 5 minutes, then cooled to room temperature. Afterward, $10 \mathrm{ml}$ of distilled water was added to each tube and their absorbances were measured at $540 \mathrm{~nm}$. The alpha-amylase activity was determined by using the maltose standard curve. One unit of enzyme activity was defined as the amount of enzyme that liberated 1 micromole of maltose per minute at $25^{\circ} \mathrm{C}$.

\section{Catalase Activity}

Catalase activity (CAT) was determined by the method of Aebi (1984), measuring the decrease in hydrogen peroxide concentration at $240 \mathrm{~nm}$. The reaction mixture contained a $20 \mu \mathrm{l}$ sample solution, 100 $\mu \mathrm{l} \mathrm{H}_{2} \mathrm{O}_{2}$ substrate, and $2.5 \mathrm{ml}$ phosphate buffer $(\mathrm{pH}$ 7). 
The absorbance of $\mathrm{H}_{2} \mathrm{O}_{2}$ at $240 \mathrm{~nm}$ is measured for $1 \mathrm{~min}$ in kinetic mode using a spectrophotometer. One unit of catalase activity is defined as the amount of enzyme necessary to decompose one micromole of $\mathrm{H}_{2} \mathrm{O}_{2}$ at 25 ${ }^{\circ} \mathrm{C}$.

\section{SOD Activity}

The activity of superoxide dismutase (SOD) is analyzed according to the method of Marklund and Marklund (1974) based on the auto-oxidation of pyrogallol. To a tube containing $2.9 \mathrm{ml}$ of Tris-EDTA buffer ( $\mathrm{pH} \mathrm{8.2)} \mathrm{and} 50 \mu \mathrm{l}$ of $20 \mathrm{mmol}$ pyrogallol, $50 \mu \mathrm{l}$ of the sample is added. The rate of auto-oxidation of pyrogallol is measured by a spectrophotometer at 325 $\mathrm{nm}$ for 60 seconds in kinetic mode. One unit of SOD activity is defined as the amount of SOD inhibiting 50\% of pyrogallol auto-oxidation at $25^{\circ} \mathrm{C}$.

Enzyme activities are expressed in specific activity (unit/mg protein). Protein concentration in the samples was determined by the method of (Lowry et al., 1951).

\section{Statistical Analysis}

The results are expressed as means \pm standard deviation. Means were compared using one-way ANOVA followed by a Tukey HSD test when significant differences were found at $P<0.05$. The homogeneity of the variances was verified by Cochran C, Hartley, Bartlett tests. The data were analyzed using STATISTICA 8.0 software.

\section{Results}

\section{Water Quality Parameters}

The results of mean values obtained from water physicochemical analysis are shown in Table 1. Average water temperatures are around $24{ }^{\circ} \mathrm{C}$ and dissolved oxygen levels were above $6 \mathrm{mg} / \mathrm{l}$ during the whole phase of the experiment in all treatments. $\mathrm{pH}$ and alkalinity were significantly lower in the BFT treatments compared to the control, with the lowest values in the BFT14 treatment. The lowest ammonium and nitrite concentrations are recorded in the BFT20 and control groups. Nitrate levels were higher in the BFT treatments compared to the control, with the highest values recorded in the BFT14 group. TSS and SS in the BFT treatments increased significantly with the increase in the $\mathrm{C} / \mathrm{N}$ ratio.

The variation of physicochemical parameters during the experiment is shown in Figure 1. A large fluctuation in $\mathrm{NH}_{4}{ }^{+}, \mathrm{NO}_{2}{ }^{-}$and $\mathrm{NO}_{3}{ }^{-}$concentrations was observed in the biofloc treatments. Levels remain within acceptable limits for Tilapia (DeLong et al., 2009). $\mathrm{NH}_{4}{ }^{+}$, $\mathrm{NO}_{2}{ }^{-}$and $\mathrm{NO}_{3}{ }^{-}$concentrations decreased as $\mathrm{C} / \mathrm{N}$ ratios increased, with the lowest concentrations observed in BFT20 and control groups. Water alkalinity is more stable in the control group and decreases steadily over time in the biofloc system, with the lowest values recorded in the BFT14 group. TSS and SS increase steadily over time in the biofloc system to reach maximum values at the end of the experiment $(>1000$ $\mathrm{mg} / \mathrm{L})$.

\section{Zootechnical Parameters}

The results of the fish yield parameters are given in Table 2. During the whole of the experiment, no mortalities were registered in all treatments reflecting the good conditions under which the experiment was conducted. After 30 days of rearing, the analysis of growth and feed conversion indices showed no significant differences between the different experimental groups. At the end of the experiment, differences in growth were recorded between tilapia reared in a biofloc system and those reared in clear water, with a significant difference in growth rates observed between the BFT20 and control group. The final stocking density in group BFT20 was significantly lower than in BFT14 and control treatments. The feed conversion ratio was significantly higher in BFT20 compared to other groups.

\section{Digestive Enzyme Activities}

Analysis of enzyme activity in the digestive tract and liver of Tilapia juveniles showed no significant

Table 1. Mean values \pm standard deviation of water quality parameters in the experiment using different $\mathrm{C} / \mathrm{N}$ ratios in biofloc rearing system of Nile tilapia juveniles compared to control treatment in clear water.

\begin{tabular}{lcccc}
\hline & $\mathrm{C}$ & BFT 14 & BFT 17 & BFT 20 \\
\hline $\mathrm{T}\left({ }^{\circ} \mathrm{C}\right)$ & $24.15 \pm 0.19$ & $24.19 \pm 0,10$ & $24.12 \pm 0.02$ & $23.97 \pm 0.20$ \\
$\mathrm{DO}(\mathrm{mg} / \mathrm{l})$ & $6.60 \pm 0.15$ & $6.18 \pm 0.29$ & $6,32 \pm 0.22$ & $6.17 \pm 0.21$ \\
$\mathrm{pH}$ & $8.04 \pm 0.005^{\mathrm{a}}$ & $7.72 \pm 0.01^{\mathrm{b}}$ & $7.82 \pm 0.01^{\mathrm{c}}$ & $7.85 \pm 0.01^{\mathrm{d}}$ \\
$\mathrm{NH}_{4^{+}}(\mathrm{mg} / \mathrm{l})$ & $0.11 \pm 0.02^{\mathrm{a}}$ & $0.25 \pm 0.03^{\mathrm{b}}$ & $0.18 \pm 0.01^{\mathrm{c}}$ & $0.14 \pm 0.01^{\mathrm{ac}}$ \\
$\mathrm{NO}_{2^{-}}(\mathrm{mg} / \mathrm{l})$ & $0.12 \pm 0.03^{\mathrm{a}}$ & $0.29 \pm 0.02^{\mathrm{b}}$ & $0.18 \pm 0.02^{\mathrm{c}}$ & $0.10 \pm 0.02^{\mathrm{a}}$ \\
$\mathrm{NO}_{3}{ }^{-}(\mathrm{mg} / \mathrm{l})$ & $7.19 \pm 0.64^{\mathrm{a}}$ & $142 \pm 8.17^{\mathrm{b}}$ & $77 \pm 7.48^{\mathrm{c}}$ & $44.76 \pm 6.72^{\mathrm{d}}$ \\
$\mathrm{Alk}(\mathrm{mg} / \mathrm{l})$ & $177.5 \pm 2,76^{\mathrm{a}}$ & $159.7 \pm 1.682^{\mathrm{b}}$ & $165.33 \pm 2,214^{\mathrm{c}}$ & $168.77 \pm 1.762^{\mathrm{d}}$ \\
$\mathrm{TSS}(\mathrm{mg} / \mathrm{l})$ & - & $465.9 \pm 27.4^{\mathrm{a}}$ & $619.8 \pm 21.9^{\mathrm{b}}$ & $750.5 \pm 30.2^{\mathrm{c}}$ \\
$\mathrm{SS}(\mathrm{ml} / \mathrm{l})$ & - & $42.58 \pm 0,5^{\mathrm{a}}$ & $52.22 \pm 2.02^{\mathrm{b}}$ & $59.44 \pm 1.84^{\mathrm{c}}$ \\
\hline
\end{tabular}

Values on the same row with different superscript letters are significantly different $(P<0,05)$. 

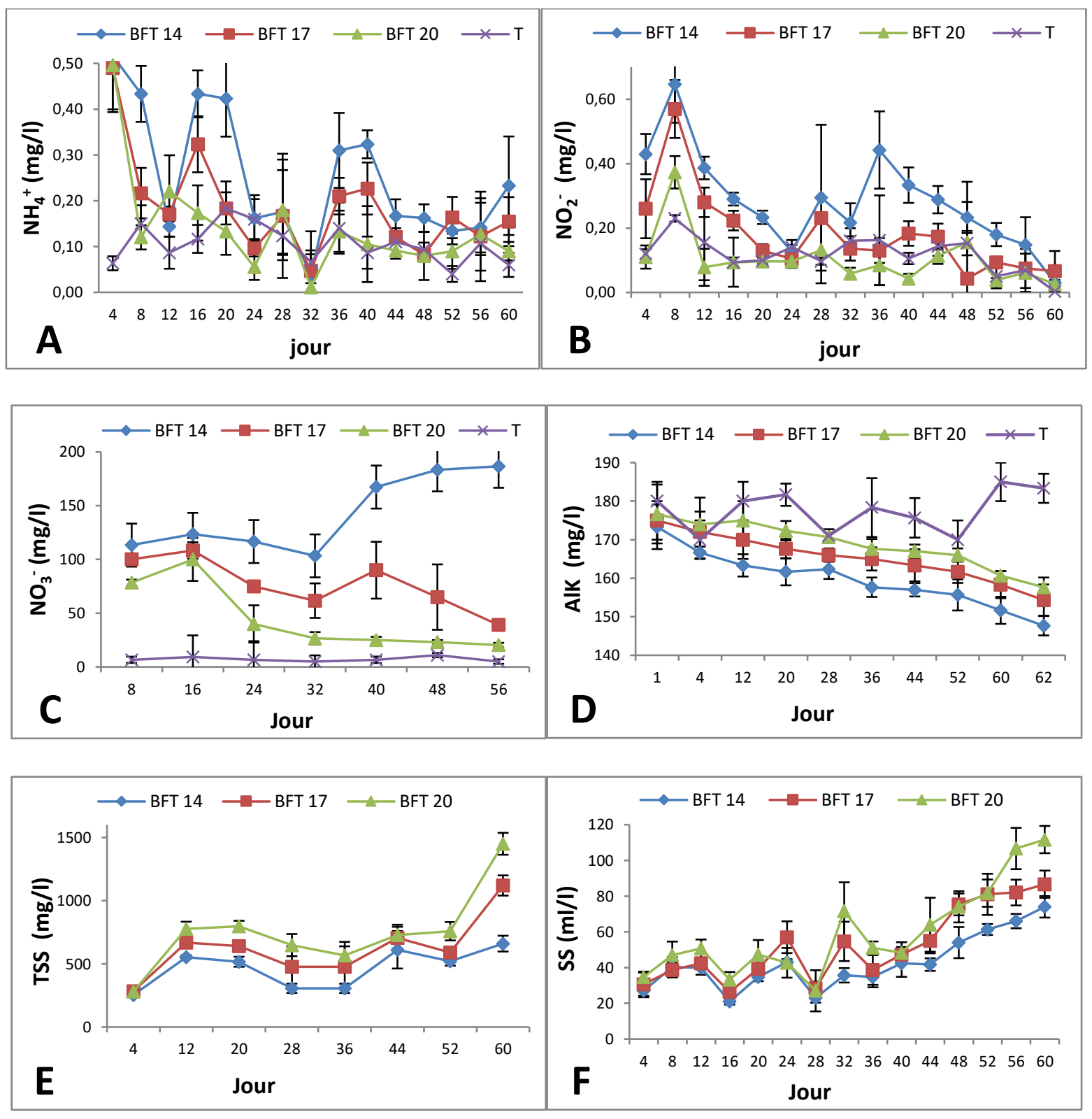

Figure 1. Dynamic changes in water quality parameters in control and biofloc tanks throughout the experimental period. (A) $\mathrm{NH}_{4}^{+}$, (B) $\mathrm{NO}_{2}^{-}$, (C) $\mathrm{NO}_{3}^{-}$, (D) Alkalinity, (E) TSS, (F) SS. Values are means ( \pm SD) of three replicates tanks per group for each sampling date.

Table 2: Growth performance of Tilapia juveniles after 30 and 62 days of rearing in the biofloc system at different $\mathrm{C} / \mathrm{N}$ ratios and in a control group.

\begin{tabular}{lccccccc}
\hline & IBW $(\mathrm{g})$ & FBW $(\mathrm{g})$ & DWG $(\mathrm{g} / \mathrm{d})$ & SGR $(\% / \mathrm{d})$ & FSD $(\mathrm{kg} / \mathrm{m} 3)$ & FCR & S $(\%)$ \\
\hline Day 30 & & & & & & & \\
C & $24.26 \pm 0.08$ & $43.2 \pm 1.2$ & $0.63 \pm 0.04$ & $1.93 \pm 0.08$ & $4.3 \pm 0.1$ & $0.93 \pm 0.05$ & $100 \pm 0$ \\
BFT14 & $24.29 \pm 0.13$ & $42.5 \pm 0.9$ & $0.61 \pm 0.02$ & $1.86 \pm 0.05$ & $4.2 \pm 0.1$ & $0.92 \pm 0.05$ & $100 \pm 0$ \\
BFT17 & $24.27 \pm 0.16$ & $41.2 \pm 0.3$ & $0.58 \pm 0.01$ & $1.79 \pm 0.01$ & $4.1 \pm 0.1$ & $0.98 \pm 0.04$ & $100 \pm 0$ \\
BFT20 & $24.15 \pm 0.09$ & $41.3 \pm 1.5$ & $0.57 \pm 0.05$ & $1.79 \pm 0.13$ & $4.1 \pm 0.2$ & $0.97 \pm 0.08$ & $100 \pm 0$ \\
Day 62 & & & & & & \\
C & $43.2 \pm 1.2$ & $76.28 \pm 3.37^{\mathrm{a}}$ & $0.84 \pm 0,05^{\mathrm{a}}$ & $1.85 \pm 0.07^{\mathrm{a}}$ & $7.6 \pm 0.3^{\mathrm{a}}$ & $1.00 \pm 0.07^{\mathrm{a}}$ & $100 \pm 0^{\mathrm{a}}$ \\
BFT14 & $42.5 \pm 0.9$ & $72.13 \pm 2.11^{\mathrm{ab}}$ & $0.77 \pm 0.04^{\mathrm{ab}}$ & $1.75 \pm 0.05^{\mathrm{ab}}$ & $7.1 \pm 0.1^{\mathrm{a}}$ & $1.02 \pm 0.04^{\mathrm{a}}$ & $100 \pm 0^{\mathrm{a}}$ \\
BFT17 & $41.2 \pm 0.3$ & $67.78 \pm 5.56^{\mathrm{ab}}$ & $0.70 \pm 0.09^{\mathrm{ab}}$ & $1.65 \pm 0.14^{\mathrm{ab}}$ & $6.8 \pm 0.6^{\mathrm{ac}}$ & $1.05 \pm 0.08^{\mathrm{a}}$ & $100 \pm 0^{\mathrm{a}}$ \\
BFT20 & $41.3 \pm 1.5$ & $62.15 \pm 4.12^{\mathrm{b}}$ & $0.61 \pm 0.07^{\mathrm{b}}$ & $1.52 \pm 0.12^{\mathrm{b}}$ & $6.1 \pm 0.3^{\mathrm{c}}$ & $1.11 \pm 0.12^{\mathrm{b}}$ & $100 \pm 0^{\mathrm{a}}$ \\
\hline
\end{tabular}

Each value represents means \pm SD. Values from the same column and the same sampling times with different superscript letters are significantly different $(P<0,05)$. 
differences between the different groups. The specific activity of proteases ranged from $50.4 \pm 8.9$ to $56 \pm 11.7$ $\mathrm{U} / \mathrm{mg}$ protein in the digestive tract and from $0.39 \pm 0.16$ to $0.49 \pm 0.52$ in the liver (Figure 2). Alpha-amylase activity varying from $4.1 \pm 0.5$ to $4.8 \pm 0.5 \mathrm{U} / \mathrm{mg}$ proteins in the digestive tract and from $3.5 \pm 0.3$ to $4.5 \pm 1.3 \mathrm{U} / \mathrm{mg}$ proteins in the liver (Figure 3 ).

\section{Antioxidant Status}

The results show that no significant differences in antioxidant enzyme activity were found between the different groups. The values range from $171.9 \pm 19.5$ to $197.7 \pm 20.4 \mathrm{U} / \mathrm{mg}$ proteins for catalase activity and from $74.3 \pm 3.2$ to $78.6 \pm 7 \mathrm{U} / \mathrm{mg}$ proteins for SOD activity (Figure 4).

\section{Discussion}

In the biofloc system, the control of water quality parameters and the understanding of their dynamics and interactions are essential for the best management of the production cycle (Emerenciano et al., 2017). The monitoring of nitrogen substances concentration is the main objective for the management of environmental parameters in all aquaculture production systems (Hargreaves, 2013). Three conversion pathways are implicated in the ammonia nitrogen removal process in the biofloc system: absorption by photoautotrophic algae, nitrification by chemoautotrophic bacteria, and assimilation by heterotrophic bacteria (Ebeling et al., 2006; Hargreaves, 2006). The contribution of each of these pathways in a biofloc system is mainly determined by the $\mathrm{C} / \mathrm{N}$ ratio applied (Ebeling et al., 2006). In this study, temperature and dissolved oxygen values were similar between the different experimental groups, and remain within the acceptable limit for the good development of Tilapia (El-Sayed, 2006). The decrease in $\mathrm{pH}$ and alkalinity in the biofloc groups compared to the control is due to the use of inorganic carbon by autotrophic and heterotrophic bacteria (Ebeling et al., 2006). The lower alkalinity values in the BFT14 group

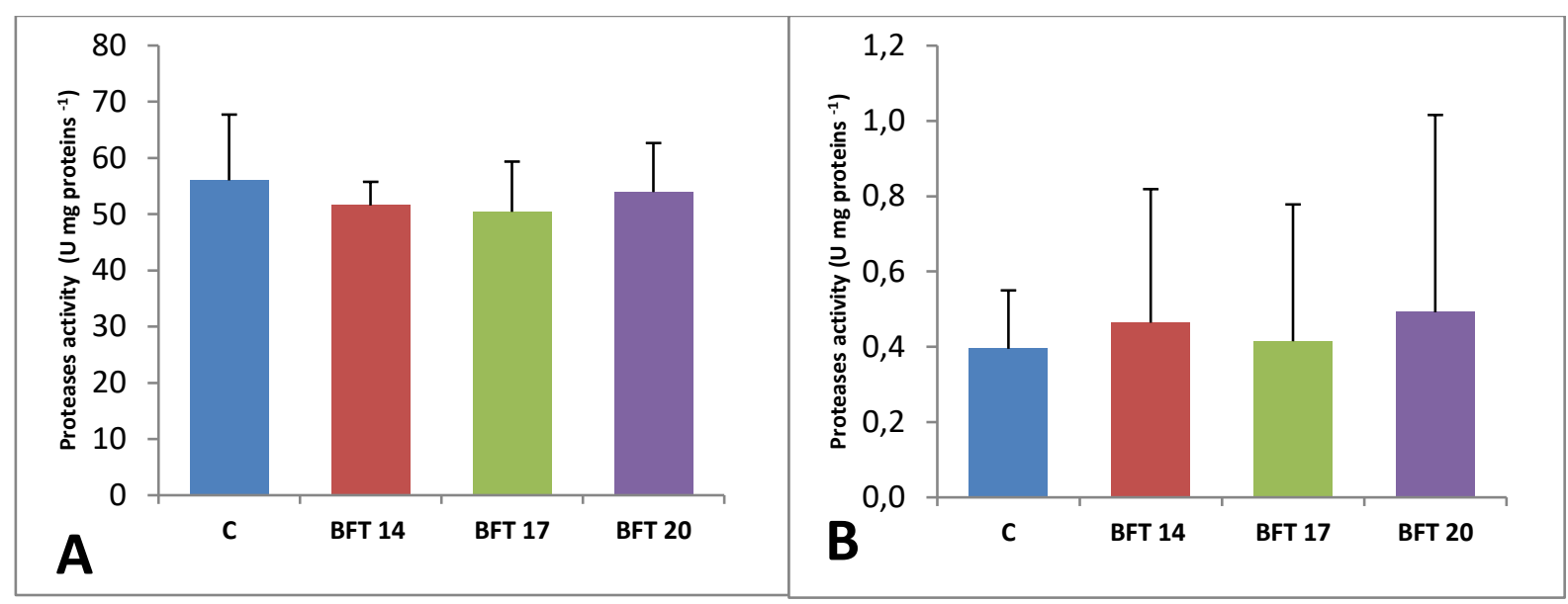

Figure 2. Specific activity of proteases in the digestive tract $(A)$ and liver (B) of tilapia juveniles from the different experimental groups. The values are expressed as means \pm SD $(n=3)$.

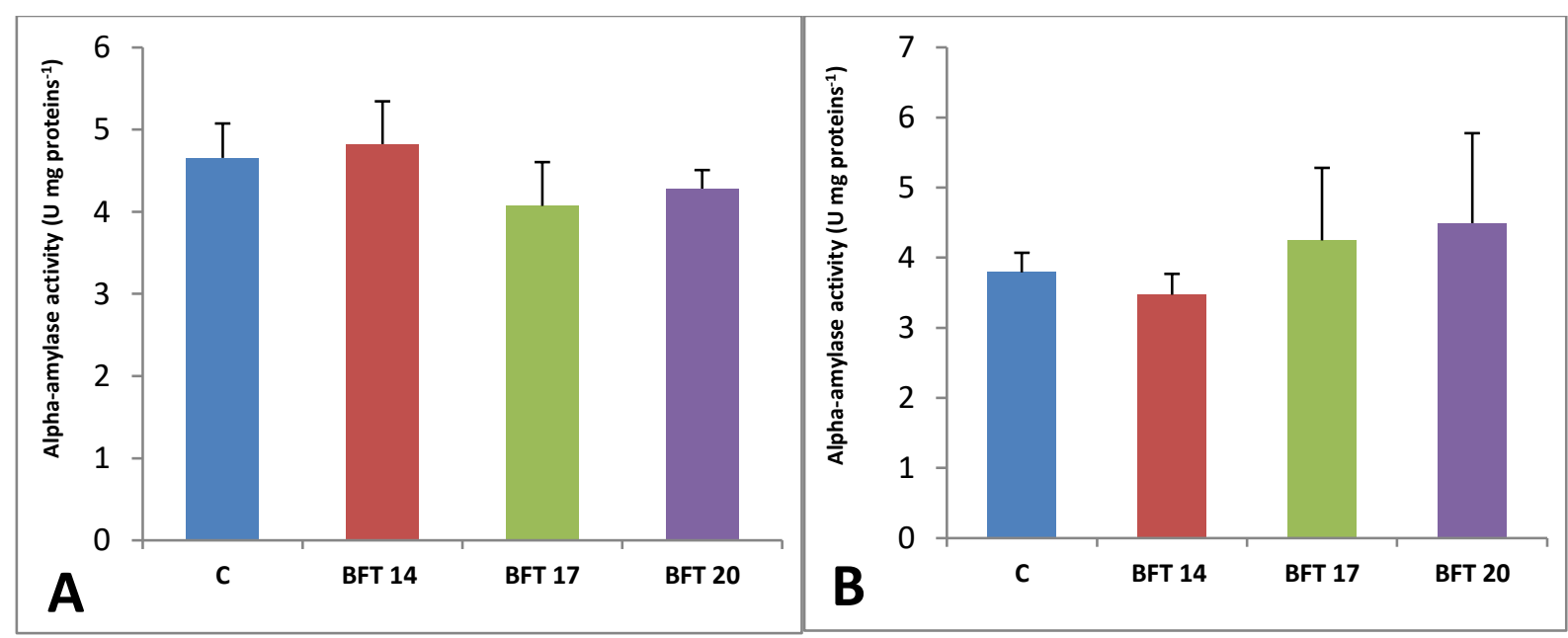

Figure 3. Specific activity of alpha-amylase in the digestive tract (A) and liver (B) of tilapia juveniles from the different experimental groups. The values are expressed as means \pm SD $(n=3)$. 


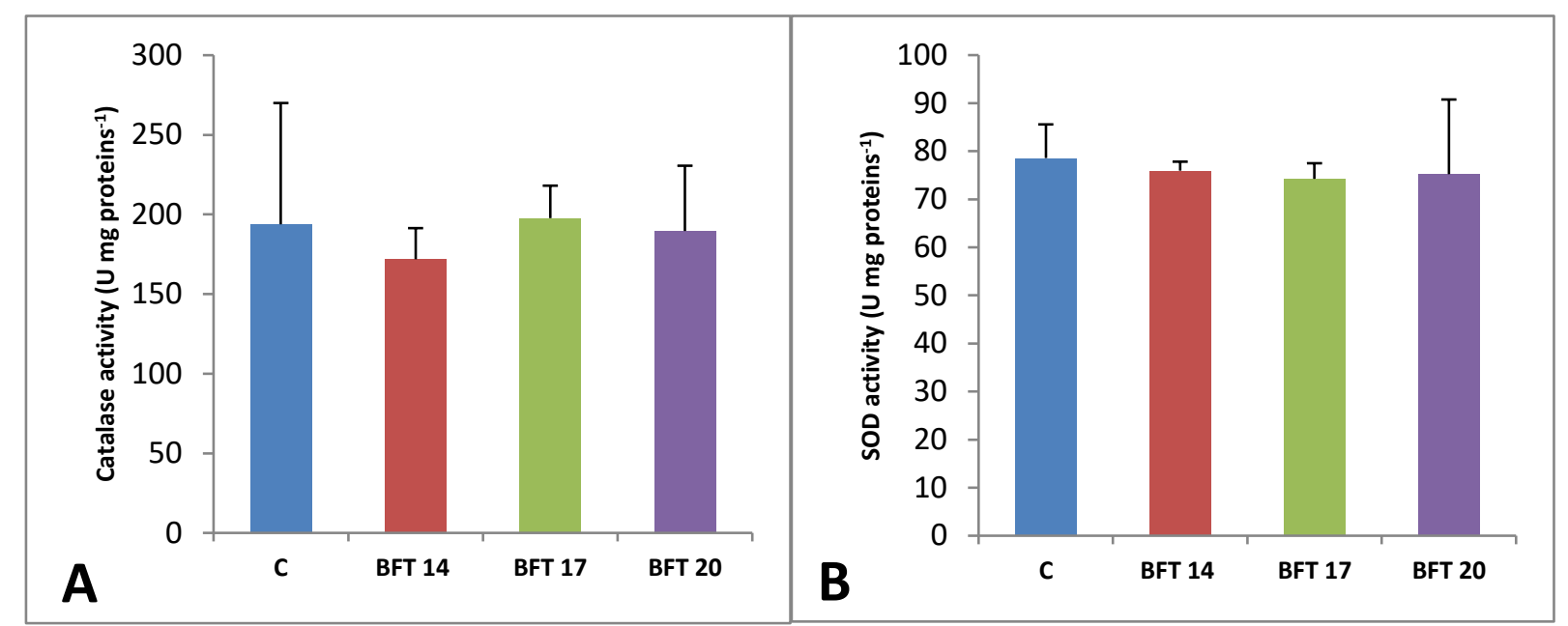

Figure 4. Specific activity of catalase (A) and SOD (B) in the liver of Tilapia juveniles from different experimental groups. The values are expressed as means $\pm S D(n=3)$.

compared to the BFT17 and BFT 20 groups may be due to the higher contribution of nitrifying bacteria in the ammonia nitrogen removal process in this group. According to Ebeling et al. (2006), for each gram of ammonium converted to nitrate, $7.05 \mathrm{~g}$ of alkalinity is consumed by nitrifying bacteria, while the conversion of $1 \mathrm{~g}$ of ammonium by heterotrophic bacteria consumes $3.57 \mathrm{~g}$ of alkalinity. In this experiment, the dynamics of the nitrogenous substances in BFT treatments showed that the nitrogen removal process is different depending on the $\mathrm{C} / \mathrm{N}$ ratio used. In the BFT14 group, the high nitrite and nitrate levels show that nitrification is the main process used, indicating the dominance of the autotrophic pathway of ammonia immobilization. Autotrophic bacteria convert ammonia-nitrogen to nitrite and then to nitrate and heterotrophic bacteria assimilate ammonia-nitrogen directly into bacterial protein (Ebeling et al., 2006; Luo et al., 2020). The increase in the $\mathrm{C} / \mathrm{N}$ ratio to 17 and then 20 in the BFT17 and BFT20 treatments promoted the development of heterotrophic bacteria that directly assimilate ammonium, which explains the low nitrate concentrations in these groups. In the BFT system, the dominance of the heterotrophic nitrogen uptake pathway is characterized by low nitrate levels (Kamilya et al., 2017; Ray \& Lotz, 2014). Our results support the work of other researchers indicating that increasing the $\mathrm{C} / \mathrm{N}$ ratio favors the dominance of heterotrophic bacteria in BFT systems (Liu et al., 2018; Silva et al., 2017; Xu et al., 2016). Xu et al. (2016), suggest that the net heterotrophic biofloc was achieved after increasing the $\mathrm{C} / \mathrm{N}$ ratio to 18 or higher. Heterotrophic bacteria have a higher maximum growth rate compared to nitrifying bacteria (Ebeling et al., 2006; Hargreaves, 2006), which may explain the faster stabilization of ammonium and nitrite levels in the BFT20 group.

Dissolved inorganic nitrogen $\left(\mathrm{NH}_{4}^{+}, \mathrm{NO}_{2}^{-}\right.$and $\left.\mathrm{NO}_{3}{ }^{-}\right)$ concentrations in all experimental groups, remained within the acceptable range for Tilapia growth (Monsees et al., 2017; Webster \& Lim, 2002). These results suggest that the use of a $\mathrm{C} / \mathrm{N}$ ratio of 14 is sufficient to maintain nitrogenous compounds in the safe range for Tilapia culture. The application of higher $\mathrm{C} / \mathrm{N}$ ratios requires the use of additional quantities of molasses, which has an impact on production costs. SS and TSS are strong indicators of biofloc development (Avnimelech, 2012). In Tilapia culture, TSS and SS should be kept below 500 $\mathrm{mg} / \mathrm{L}$ and $50 \mathrm{ml} / \mathrm{L}$ respectively (Avnimelech, 2011; Emerenciano et al., 2017). During this study, the suspended solids gradually accumulate in BFT groups to reach values above $1000 \mathrm{mg} / \mathrm{L}$ at the end of the experiment in BFT17 and BFT20 groups. Similar values were recorded in biofloc systems (Azim \& Little, 2008; $\mathrm{Xu}$ et al., 2016). However, TSS levels remained below 600 in the BFT14 treatment. The increase in the $\mathrm{C} / \mathrm{N}$ ratio by the addition of molasses is associated with an increase in TSS and SS. This accumulation of TSS is due to the increase in microbial biomass resulting from the faster growth of heterotrophic bacteria (Xu et al., 2018). Furthermore, ammonia removal by heterotrophic bacteria produced 40 times more bacterial biomass than autotrophic bacteria (Ebeling et al., 2006; Xu et al., 2018).

The results of our study did not show an improvement in growth performance, feed utilization, and survival rate of juvenile Tilapia reared in the biofloc system compared to control. Similar results were obtained by Pérez-Fuentes et al. (2018) and Widanarni et al. (2012), for Tilapia.

On the other hand, several studies have reported improved growth performance and feed utilization of Tilapia in biofloc systems (Azim \& Little, 2008; Haraz et al., 2018; Hisano et al., 2019; Liu et al., 2018; Long et al., 2015; Luo et al., 2014; Mirzakhani et al., 2019). The improvement in growth performance and feed efficiency of fish in BFT systems is linked to improved water quality and the use of biofloc as an additional source of food. Studies based on the nitrogen isotope 
tagging techniques have confirmed the use of biofloc as a food source for tilapia (Avnimelech, 2007) and shrimp (Burford et al., 2004). In our experiment, the artificial pellets were distributed to satiety at a frequency of three times a day in all the tanks, which probably reduced the contribution of the biofloc in the feeding of the juvenile tilapia. The application of feed deprivation periods of up to 3 days per week improved the feed efficiency of Tilapia in biofloc systems without affecting growth performance (Correa et al., 2020). In this context, (Cavalcante et al., 2017) indicated that the reduction in feed ration by $15 \%$ did not affect the growth and feed efficiency of Tilapia in the biofloc system. This indicates that the dietary restriction promotes the use of the biofloc as a food source for fish.

This study did not find a significant effect of increasing the $\mathrm{C} / \mathrm{N}$ ratio on the growth performance of tilapia. However, we found a lower growth rate in the BFT20 treatment when compared with the control. The tilapia in the BFT20 treatment had lower feed efficiency than tilapia in the BFT14, BFT17, and control groups. The high TSS values above $700 \mathrm{mg} / \mathrm{L}$ may affect tilapia growth and feed intake in the BFT20 group. Generally, high levels of suspended solids can reduce growth and cause gill obstruction in fish and shrimp (Azim \& Little, 2008; Schveitzer et al., 2013).

Previous studies on tilapia culture have indicated a negative effect on growth and feed utilization in BFT treatments with $\mathrm{C} / \mathrm{N}$ ratios greater than 15 (Liu et al., 2018; Pérez-Fuentes et al., 2018). Similar results were obtained in shrimp culture with a better zootechnical performance recorded in BFT treatments with lower $\mathrm{C} / \mathrm{N}$ ratios (Chakrapani et al., 2021; Xu et al., 2016, 2018). On the other hand, Wang et al. (2015) reported improved growth and feed utilization indices in $\mathrm{C} / \mathrm{N}$ ratios of 20 and 25 compared to $\mathrm{C} / \mathrm{N}$ ratios of 15 in Carassius auratus (Linnaeus, 1758) culture. Similarly, Minabi et al. (2020) found that a C/N ratio of 19 appears to provide better growth and feed utilization and biochemical composition of the common carp. Xu et al. (2016), suggest that the mixed biofloc type dominated by microalgae and autotrophic bacteria is more beneficial for shrimp development compared to the biofloc system dominated by heterotrophic bacteria. The optimization of the best $\mathrm{C} / \mathrm{N}$ ratio for the good development of fish and shrimp in biofloc systems is still under discussion. This study showed that it is possible to reduce the $\mathrm{C} / \mathrm{N}$ ratio to 14 without negative effects on water quality and tilapia growth in BFT system.

Several previous studies have investigated the contribution of the biofloc on the stimulation of digestive enzyme activity in fish (Liu et al., 2018; Luo et al., 2014; Sontakke et al., 2021; Yu et al., 2020) and shrimp (Anand et al., 2014; Cardona et al., 2016; Wang et al., 2016; Xu et al., 2013). Generally, increased digestive enzyme activity has been associated with improved growth and feed utilization. The stimulation of digestive enzyme activity may due to the contribution of extracellular enzymes released by microorganisms associated with the floc and endogenous enzymes stimulated by certain bioactive components contained in the biofloc (Wang et al., 2016; Xu et al., 2013).

The current study shows that there is no significant effect of the biofloc system on the activity of proteases and alpha-amylase in the digestive tract and liver of Tilapia. This is consistent with the results obtained for growth performance and feed utilization, which is probably due to the low contribution of the biofloc in the diet of juvenile Tilapia during this experiment. We did not find any significant influence of the increase in the $\mathrm{C} / \mathrm{N}$ ratio from 14 to 20 on digestive enzyme activity. These results are in agreement with previous findings where no significant differences in activities of proteases and amylase were found between $\mathrm{C} / \mathrm{N}$ ratios of 15 and 20 in Litopenaeus vannamei culture (Xu \& Pan, 2012). This was in contrast to the results of Liu et al. (2018) and Yu et al. (2020), who reported that increasing the $\mathrm{C} / \mathrm{N}$ ratio enhanced the digestive enzyme activity in the tilapia and golden crucian carp.

The antioxidant status can reflect the health status of fish (Martins et al., 2019; Shourbela et al., 2021). Various factors associated with unsuitable conditions in aquaculture systems such as water quality parameters, chemical pollutants, diet, stocking density, and pathologies can induce oxidative stress in fish (Bakhshi et al., 2018; Birnie-Gauvin et al., 2017; Cavalcanti Nery et al., 2019; Chowdhury \& Saikia, 2020; Dawood et al., 2019). CAT and SOD are among the main enzymes used for the removal of reactive oxygen species, which are indicators of oxidative stress in fish (Kovacik, 2017). SOD catalyzes the dismutation of superoxide radicals to oxygen and hydrogen peroxide, which is subsequently eliminated by CAT, preventing the beginning of lipid peroxidation (Hoseinifar et al., 2021; Shourbela et al., 2021).

In the present study, there were no significant differences in the CAT and SOD activities between control and BFT treatments. Similar results were obtained for SOD activity in tilapia raised in BFT systems (Bakhshi et al., 2018; Long et al., 2015). However, other studies have shown that biofloc system enhanced SOD (Liu et al., 2018; Luo et al., 2014; Zaki et al., 2020) and CAT (Mansour \& Esteban, 2017; Shourbela et al., 2021) activities in tilapia. The absence of impact on antioxidant capacity in this study may indicate that the biofloc environment did not alter the health status of tilapia juveniles.

\section{Conclusions}

In general, this study has shown that the dynamics of water quality parameters in BFT systems are influenced by the $\mathrm{C} / \mathrm{N}$ ratio used, through the control of the balance between autotrophic and heterotrophic communities, which are responsible the removal of the nitrogenous substances. The $\mathrm{C} / \mathrm{N}$ ratio can be reduced up to 14 without affecting the growth performance, feed utilization and physiological parameters of juvenile 
tilapia. The application of a lower $\mathrm{C} / \mathrm{N}$ ratio allows reducing the production costs by limiting the molasses addition and decreasing the water renewal, which is linked to the TSS accumulation. The rearing of tilapia juveniles in the biofloc system did not alter the studied physiological parameters such as the digestive enzymes activity, and the antioxidant status, which indicate that the biofloc environment did not induce stress in fish.

\section{Ethical Statement}

The handling of experimental animals (Tilapia juveniles) was performed in accordance with the recommendations in the international guiding principles for biomedical research involving animals (ICLAS, 2012). All manipulation was performed under anesthesia, and all efforts were made to minimize animal stress.

\section{Funding Information}

The authors received no specific funding for this work.

\section{Author Contribution}

DA: conceived and planned the experiments, carried out the experiment, drafted the article; WR: supervised the project, revised and approved the version to be published; AM: helped carry out the laboratory analysis, contributed to the final manuscript.

\section{Conflict of Interest}

The authors declare that they have no known competing financial interests or personal relationships that could have appeared to influence the work reported in this paper.

\section{Acknowledgements}

We would like to thank the director of the marine fish farming experimental station for facilitating the conduct of experiments.

\section{References}

Aebi, H. (1984). [13] Catalase in vitro. In Methods in Enzymology (Vol. 105, pp. 121-126). Academic Press. https://doi.org/10.1016/S0076-6879(84)05016-3

Ahmad, I., Rani, A. B., Verma, A., \& Maqsood, M. (2017). Biofloc technology: an emerging avenue in aquatic animal healthcare and nutrition. Aquaculture International, 25(3), 1215-1226. https://doi.org/10.1007/s10499-016-0108-8

Anand, P. S. S., Kohli, M. P. S., Kumar, S., Sundaray, J. K., Roy, S. D., Venkateshwarlu, G., . . Pailan, G. H. (2014). Effect of dietary supplementation of biofloc on growth performance and digestive enzyme activities in Penaeus monodon. Aquaculture, 418-419, 108-115. https://doi.org/10.1016/j.aquaculture.2013.09.051
Anasori, N., Farahnak, A., Golmohamadi, T., Eshraghian, M., \& Molaei Rad, M. (2015). Comparative assay of protease enzyme activity in protoscolices (Hydatid cyst) and liver tissues. Archives of Advances in Biosciences, 6(1). https://doi.org/10.22037/jps.v6i1.8116

Avnimelech, Y. (2007). Feeding with microbial flocs by tilapia in minimal discharge bio-flocs technology ponds. Aquaculture, 264(1), 140-147.

https://doi.org/10.1016/j.aquaculture.2006.11.025

Avnimelech, Y. (2011). Tilapia production using biofloc technology, saving water, waste recycling improves economics. Global aquaculture Advocate, 2011, 66-68.

Avnimelech, Y. (2012). Biofloc technology: a practical guide book (2nd ed. ed.). Baton Rouge (La.): World aquaculture society.

Avnimelech, Y., \& Kochba, M. (2009). Evaluation of nitrogen uptake and excretion by tilapia in bio floc tanks, using $15 \mathrm{~N}$ tracing. Aquaculture, 287(1), 163-168. https://doi.org/10.1016/j.aquaculture.2008.10.009

Azhar, M. H., Suciyono, S., Budi, D. S., Ulkhaq, M. F., Anugrahwati, M., \& Ekasari, J. (2020). Biofloc-based coculture systems of Nile tilapia (Oreochromis niloticus) and redclaw crayfish (Cherax quadricarinatus) with different carbon-nitrogen ratios. Aquaculture International, 28(3), 1293-1304. https://doi.org/10.1007/s10499-020-00526-z

Azim, M. E., \& Little, D. C. (2008). The biofloc technology (BFT) in indoor tanks: Water quality, biofloc composition, and growth and welfare of Nile tilapia (Oreochromis niloticus). Aquaculture, 283(1), 29-35. https://doi.org/10.1016/j.aquaculture.2008.06.036

Bakhshi, F., H Najdegerami, E., Manaffar, R., Tokmechi, A., Rahmani Farah, K., \& Shalizar Jalali, A. (2018). Growth performance, haematology, antioxidant status, immune response and histology of common carp (Cyprinus carpio L.) fed biofloc grown on different carbon sources. Aquaculture Research, 49(1), 393-403. https://doi.org/10.1111/are.13469

Bernfeld, P. (1955). [17] Amylases, $\alpha$ and $\beta$. In Methods in Enzymology (Vol. 1, pp. 149-158). Academic Press. https://doi.org/10.1016/0076-6879(55)01021-5

Birnie-Gauvin, K., Costantini, D., Cooke, S. J., \& Willmore, W. G. (2017). A comparative and evolutionary approach to oxidative stress in fish: A review. Fish and Fisheries, 18(5), 928-942. https://doi.org/10.1111/faf.12215

Bossier, P., \& Ekasari, J. (2017). Biofloc technology application in aquaculture to support sustainable development goals. Microb Biotechnol, 10(5), 1012-1016. https://doi.org/10.1111/1751-7915.12836

Burford, M. A., Thompson, P. J., McIntosh, R. P., Bauman, R. H., \& Pearson, D. C. (2004). The contribution of flocculated material to shrimp (Litopenaeus vannamei) nutrition in a high-intensity, zero-exchange system. Aquaculture, 232(1), 525-537. https://doi.org/10.1016/S00448486(03)00541-6

Cardona, E., Lorgeoux, B., Chim, L., Goguenheim, J., Le Delliou, H., \& Cahu, C. (2016). Biofloc contribution to antioxidant defence status, lipid nutrition and reproductive performance of broodstock of the shrimp Litopenaeus stylirostris: Consequences for the quality of eggs and larvae. Aquaculture, 452, 252-262. https://doi.org/10.1016/j.aquaculture.2015.08.003

Cavalcante, D. d. H., Lima, F. R. d. S., Rebouças, V. T., \& Sá, M. V. d. C. (2017). Nile tilapia culture under feeding restriction in bioflocs and bioflocs plus periphyton tanks. 
Acta Scientiarum. Animal Sciences, 39, 223-228. https://doi.org/10.4025/actascianimsci.v39i3.33574

Cavalcanti Nery, R., Costa, C. B., Rodrigues, F., Soares, R., Bezerra, R. d. S., \& Peixoto, S. (2019). Effect of feeding frequency on growth and digestive enzyme activity in Litopenaeus vannameiduring the grow-out phase in biofloc system. Aquaculture Nutrition, 25(3), 577-584. https://doi.org/10.1111/anu.12880

Chakrapani, S., Panigrahi, A., Sundaresan, J., Sivakumar, M. R., Palanisamy, R., \& Kumar, V. (2021). Three different C: N ratios for Pacific white shrimp, Penaeus vannamei under practical conditions: Evaluation of growth performance, immune and metabolic pathways. Aquaculture Research, 52(3), 1255-1266. https://doi.org/10.1111/are.14984

Chowdhury, S., \& Saikia, S. (2020). Oxidative stress in fish: a review. Journal of Scientific Research, 12(1), 145-160. https://doi.org/10.3329/jsr.v12i1.41716

Correa, A. d. S., Pinho, S. M., Molinari, D., Pereira, K. d. R., Gutiérrez, S. M., Monroy-Dosta, M. d. C., \& Emerenciano, M. G. C. (2020). Rearing of Nile tilapia (Oreochromis niloticus) juveniles in a biofloc system employing periods of feed deprivation. Journal of Applied Aquaculture, 32(2), 139-156. https://doi.org/10.1080/10454438.2019.1679319

Crab, R., Defoirdt, T., Bossier, P., \& Verstraete, W. (2012). Biofloc technology in aquaculture: Beneficial effects and future challenges. Aquaculture, 356-357, 351-356. https://doi.org/10.1016/j.aquaculture.2012.04.046

Crab, R., Kochva, M., Verstraete, W., \& Avnimelech, Y. (2009). Bio-flocs technology application in over-wintering of tilapia. Aquacultural Engineering, 40(3), 105-112. https://doi.org/10.1016/j.aquaeng.2008.12.004

Dauda, A. B. (2020). Biofloc technology: a review on the microbial interactions, operational parameters and implications to disease and health management of cultured aquatic animals. Reviews in Aquaculture, 12(2), 1193-1210. https://doi.org/10.1111/raq.12379

Dawood, M. A., Shukry, M., Zayed, M. M., Omar, A. A., Zaineldin, A. I., \& El Basuini, M. F. (2019). Digestive enzymes, immunity and oxidative status of Nile tilapia (Oreochromis niloticus) reared in intensive conditions. Slovenian Veterinary Research, 56(22), 99-108. https://doi.org/10.26873/SVR-747-2019

DeLong, D. P., Losordo, T., \& Rakocy, J. (2009). Tank culture of tilapia.

Duy, N. T., \& Van Khanh, L. (2018). Effect of molasses addition at different $\mathrm{C}$ : $\mathrm{N}$ ratios on growth and survival rate of spotted scat (Scatophagus argus) fingerling in biofloc system. International Journal of Scientific and Research Publications, 8(5), 452-459.

https://doi.org/10.29322/IJSRP.8.5.2018.p7759

Ebeling, J. M., Timmons, M. B., \& Bisogni, J. J. (2006). Engineering analysis of the stoichiometry of photoautotrophic, autotrophic, and heterotrophic removal of ammonia-nitrogen in aquaculture systems. Aquaculture, 257(1), 346-358. https://doi.org/10.1016/j.aquaculture.2006.03.019

Edwards, P. (2015). Aquaculture environment interactions: Past, present and likely future trends. Aquaculture, 447, 2-14. https://doi.org/10.1016/j.aquaculture.2015.02.001

El-Sayed, A.-F. M. (2006). Tilapia culture. Wallingford, CABI Publishing.
Emerenciano, M., Martinez-Cordova, L. R., Martinez-Porchas, M., \& Miranda-Baeza, A. (2017). Biofloc Technology (BFT): A Tool for Water Quality Management in Aquaculture. In H. Tutu (Ed.), Water Quality (pp. 91-109). IntechOpen. https://doi.org/10.5772/66416

Gaona, C. A. P., da Paz Serra, F., Furtado, P. S., Poersch, L. H., \& Wasielesky, W. (2016). Biofloc management with different flow rates for solids removal in the Litopenaeus vannamei BFT culture system. Aquaculture International, 24(5), 1263-1275. https://doi.org/10.1007/s10499-016-9983-2

Gou, J., Hong, C. U., Deng, M., Chen, J., Hou, J., Li, D., \& He, X. (2019). Effect of Carbon to Nitrogen Ratio on Water Quality and Community Structure Evolution in Suspended Growth Bioreactors through Biofloc Technology. Water, 11(8). https://doi.org/10.3390/w11081640

Haraz, Y. G., El-Hawarry, W. N., \& Shourbela, R. M. (2018). Culture Performance of Nile tilapia (Oreochromis niloticus) raised in a bioflocbased intensive system. Alexandria Journal for Veterinary Sciences, 58(1). https://doi.org/10.5455/ajvs.299795

Hargreaves, J. A. (2006). Photosynthetic suspended-growth systems in aquaculture. Aquacultural Engineering, 34(3), 344-363.

https://doi.org/10.1016/j.aquaeng.2005.08.009

Hargreaves, J. A. (2013). Biofloc production systems for aquaculture. SRAC Publication, 4503.

Hatate, H., Tanaka, R., Suzuki, N., \& Hama, Y. (2000). Comparison of protease activity in liver among several species of squid and cuttlefish. Fisheries science, 66(1), 182-183. https://doi.org/10.1046/j.1444-2906.2000.00031.x

Hisano, H., Barbosa, P. T., Hayd, L. A., \& Mattioli, C. C. (2019). Evaluation of Nile tilapia in monoculture and polyculture with giant freshwater prawn in biofloc technology system and in recirculation aquaculture system. International Aquatic Research, 11(4), 335-346. https://doi.org/10.1007/s40071-019-00242-2

Hoseinifar, S. H., Yousefi, S., Van Doan, H., Ashouri, G., Gioacchini, G., Maradonna, F., \& Carnevali, O. (2021). Oxidative Stress and Antioxidant Defense in Fish: The Implications of Probiotic, Prebiotic, and Synbiotics. Reviews in Fisheries Science \& Aquaculture, 29(2), 198217. https://doi.org/10.1080/23308249.2020.1795616

ICLAS. (2012). International guiding principles for biomedical research involving animals.

https://olaw.nih.gov/sites/default/files/Guiding_Princip les_2012.pdf

Kamilya, D., Debbarma, M., Pal, P., Kheti, B., Sarkar, S., \& Singh, S. T. (2017). Biofloc technology application in indoor culture of Labeo rohita (Hamilton, 1822) fingerlings: The effects on inorganic nitrogen control, growth and immunity. Chemosphere, 182, 8-14. https://doi.org/10.1016/j.chemosphere.2017.05.021

Khanjani, M. H., \& Sharifinia, M. (2020). Biofloc technology as a promising tool to improve aquaculture production. Reviews in Aquaculture, 12(3), 1836-1850. https://doi.org/10.1111/raq.12412

Kovacik, A. (2017). Oxidative stress in fish induced by environmental pollutants. Scientific Papers: Animal Science and Biotechnologies, 50(1), 121-125.

Krummenauer, D., Samocha, T., Poersch, L., Lara, G., \& Wasielesky Jr, W. (2014). The Reuse of Water on the Culture of Pacific White Shrimp, Litopenaeus vannamei, 
in BFT System. Journal of the World Aquaculture Society, 45(1), 3-14. https://doi.org/10.1111/jwas.12093

Liu, G., Zhu, S., Liu, D., \& Ye, Z. (2018). Effect of the C/N ratio on inorganic nitrogen control and the growth and physiological parameters of tilapias fingerlings, Oreochromis niloticu reared in biofloc systems. Aquaculture Research, 49(7), 2429-2439. https://doi.org/10.1111/are.13702

Long, L., Yang, J., Li, Y., Guan, C., \& Wu, F. (2015). Effect of biofloc technology on growth, digestive enzyme activity, hematology, and immune response of genetically improved farmed tilapia (Oreochromis niloticus). Aquaculture, 448, 135-141. https://doi.org/10.1016/j.aquaculture.2015.05.017

Lowry, O. H., Rosebrough, N. J., Farr, A. L., \& Randall, R. J. (1951). Protein measurement with the Folin phenol reagent. J Biol Chem, 193(1), 265-275.

Luo, G., Gao, Q., Wang, C., Liu, W., Sun, D., Li, L., \& Tan, H. (2014). Growth, digestive activity, welfare, and partial cost-effectiveness of genetically improved farmed tilapia (Oreochromis niloticus) cultured in a recirculating aquaculture system and an indoor biofloc system. Aquaculture, 422-423, 1-7.

https://doi.org/10.1016/j.aquaculture.2013.11.023

Luo, G., Xu, J., \& Meng, H. (2020). Nitrate accumulation in biofloc aquaculture systems. Aquaculture, 520, 734675. https://doi.org/10.1016/j.aquaculture.2019.734675

Mansour, A. T., \& Esteban, M. Á. (2017). Effects of carbon sources and plant protein levels in a biofloc system on growth performance, and the immune and antioxidant status of Nile tilapia (Oreochromis niloticus). Fish Shellfish Immunol, 64, 202-209. https://doi.org/10.1016/j.fsi.2017.03.025

Marklund, S., \& Marklund, G. (1974). Involvement of the Superoxide Anion Radical in the Autoxidation of Pyrogallol and a Convenient Assay for Superoxide Dismutase. European Journal of Biochemistry, 47(3), 469-474.

https://doi.org/10.1111/j.1432-1033.1974.tb03714.x

Martins, G. B., da Rosa, C. E., Tarouco, F. d. M., \& Robaldo, R. B. (2019). Growth, water quality and oxidative stress of Nile tilapia Oreochromis niloticus (L.) in biofloc technology system at different $\mathrm{pH}$. Aquaculture Research, 50(4), 1030-1039.

https://doi.org/10.1111/are.13975

Miller, D., \& Semmens, K. (2002). Waste management in aquaculture. West Virginia University Extension Service Publication No. AQ02-1. USA, 8.

Minabi, K., Sourinejad, I., Alizadeh, M., Ghatrami, E. R., \& Khanjani, M. H. (2020). Effects of different carbon to nitrogen ratios in the biofloc system on water quality, growth, and body composition of common carp (Cyprinus carpio L.) fingerlings. Aquaculture International, 28, 1883-1898.

https://doi.org/10.1007/s10499-020-00564-7

Mirzakhani, N., Ebrahimi, E., Jalali, S. A. H., \& Ekasari, J. (2019). Growth performance, intestinal morphology and nonspecific immunity response of Nile tilapia (Oreochromis niloticus) fry cultured in biofloc systems with different carbon sources and input C: $\mathrm{N}$ ratios. Aquaculture, 512, 734235. https://doi.org/10.1016/j.aquaculture.2019.734235

Monsees, H., Klatt, L., Kloas, W., \& Wuertz, S. (2017). Chronic exposure to nitrate significantly reduces growth and affects the health status of juvenile Nile tilapia
(Oreochromis niloticus L.) in recirculating aquaculture systems. Aquaculture Research, 48(7), 3482-3492. https://doi.org/10.1111/are.13174

MPRH. (2014). Secteur de la pêche et de l'aquaculture, Bilan (2012-2014), Prospective 2030 et projet " Plan AQUAPECHE $2020 \%$.

http://extwprlegs1.fao.org/docs/pdf/alg165014.pdf

Pérez-Fuentes, J. A., Pérez-Rostro, C. I., Hernández-Vergara, M. P., \& Monroy-Dosta, M. d. C. (2018). Variation of the bacterial composition of biofloc and the intestine of Nile tilapia Oreochromis niloticus, cultivated using biofloc technology, supplied different feed rations. Aquaculture Research, 49(11), 3658-3668. https://doi.org/10.1111/are.13834

Poli, M. A., Legarda, E. C., de Lorenzo, M. A., Martins, M. A., \& do Nascimento Vieira, F. (2019). Pacific white shrimp and Nile tilapia integrated in a biofloc system under different fish-stocking densities. Aquaculture, 498, 83-89. https://doi.org/10.1016/j.aquaculture.2018.08.045

Prabu, E., Rajagopalsamy, C., Ahilan, B., Jeevagan, I. J. M. A., \& Renuhadevi, M. (2019). Tilapia-an excellent candidate species for world aquaculture: a review. Annual Research \& Review in Biology, 1-14. https://doi.org/10.9734/ARRB/2019/v31i330052

Rajkumar, M., Pandey, P. K., Aravind, R., Vennila, A., Bharti, V., \& Purushothaman, C. S. (2016). Effect of different biofloc system on water quality, biofloc composition and growth performance in Litopenaeus vannamei (Boone, 1931). Aquaculture Research, 47(11), 3432-3444. https://doi.org/10.1111/are.12792

Ray, A. J., \& Lotz, J. M. (2014). Comparing a chemoautotrophicbased biofloc system and three heterotrophic-based systems receiving different carbohydrate sources. Aquacultural Engineering, 63, 54-61. https://doi.org/10.1016/j.aquaeng.2014.10.001

Rodier, J., Legube, B., Merlet, N., \& Brunet, R. (2009). L'analyse de l'eau - 9e éd.: Eaux naturelles, eaux résiduaires, eau de mer. Dunod. https://books.google.dz/books?id=qUEGsUBZkLOC

Saker, M. L., \& Bouhoun, M. D. (2007). Les ressources naturelles sahariennes : Gestion et impact sur le développement agricole. Annales de la Faculté des Sciences et des Sciences de l'Ingénieur, 1(2), 58-62.

Schveitzer, R., Arantes, R., Costódio, P. F. S., do Espírito Santo, C. M., Arana, L. V., Seiffert, W. Q., \& Andreatta, E. R. (2013). Effect of different biofloc levels on microbial activity, water quality and performance of Litopenaeus vannamei in a tank system operated with no water exchange. Aquacultural Engineering, 56, 59-70. https://doi.org/10.1016/j.aquaeng.2013.04.006

Shourbela, R. M., Khatab, S. A., Hassan, M. M., Van Doan, H., \& Dawood, M. A. O. (2021). The Effect of Stocking Density and Carbon Sources on the Oxidative Status, and Nonspecific Immunity of Nile tilapia (Oreochromis niloticus) Reared under Biofloc Conditions. Animals, 11(1). https://doi.org/10.3390/ani11010184

Silva, U. L., Falcon, D. R., PESSÔA, M. N. D. C., \& Correia, E. d. S. (2017). CARBON SOURCES AND C: N RATIOS ON WATER QUALITY FOR NILE TILAPIA FARMING IN BIOFLOC SYSTEM 1. Revista Caatinga, 30, 1017-1027. https://doi.org/10.1590/1983-21252017v30n423rc

Singh, J., Sarma, K., Kumar, T., Ahirwal, S., \& Keer, S. R. a. N. (2020). Bio-floc Technology (BFT): An Intensive Eco Sustainable and Cost-Effective Tool for Aquaculture. Food and Scientific Reports, 10(1). 
Sontakke, R., Tiwari, V. K., Kurcheti, P., Asanaru Majeedkutty, B. R., Ande, M. P., \& Haridas, H. (2021). Yam-based biofloc system improves the growth, digestive enzyme activity, bacterial community structure and nutritional content in milkfish (Chanos chanos). Aquaculture Research, 52(7), 3460-3474. https://doi.org/10.1111/are.15190

Tucker, C. S., Hargreaves, J. A., \& Boyd, C. E. (2008). Better Management Practices for Freshwater Pond Aquaculture. In Environmental best management practices for aquaculture (pp. 151-226). https://doi.org/10.1002/9780813818672.ch6

van der Salm, A. L., Metz, J. R., Wendelaar Bonga, S. E., \& Flik, G. (2005). Alpha-MSH, the melanocortin-1 receptor and background adaptation in the Mozambique tilapia, Oreochromis mossambicus. General and Comparative Endocrinology, 144(2), 140-149. https://doi.org/10.1016/j.ygcen.2005.05.009

Wang, C., Pan, L., Zhang, K., Xu, W., Zhao, D., \& Mei, L. (2016). Effects of different carbon sources addition on nutrition composition and extracellular enzymes activity of bioflocs, and digestive enzymes activity and growth performance of Litopenaeus vannamei in zero-exchange culture tanks. Aquaculture Research, 47(10), 3307-3318. https://doi.org/10.1111/are.12784

Wang, G., Yu, E., Xie, J., Yu, D., Li, Z., Luo, W., . . Z Zheng, Z. (2015). Effect of $C / N$ ratio on water quality in zero-water exchange tanks and the biofloc supplementation in feed on the growth performance of crucian carp, Carassius auratus. Aquaculture, 443, 98-104. https://doi.org/10.1016/j.aquaculture.2015.03.015

Webster, C. D., \& Lim, C. (2002). Nutrient requirements and feeding of finfish for aquaculture. New York, USA, Cabi Publishing.

Widanarni, Ekasari, J., \& Maryam, S. (2012). Evaluation of Biofloc Technology Application on Water Quality and Production Performance of Red Tilapia Oreochromis sp. Cultured at Different Stocking Densities. HAYATI Journal of Biosciences, 19(2), 73-80. https://doi.org/10.4308/hjb.19.2.73

Xu, W.-J., Morris, T. C., \& Samocha, T. M. (2016). Effects of C/N ratio on biofloc development, water quality, and performance of Litopenaeus vannamei juveniles in a biofloc-based, high-density, zero-exchange, outdoor tank system. Aquaculture, 453, 169-175.

https://doi.org/10.1016/j.aquaculture.2015.11.021

Xu, W.-J., Morris, T. C., \& Samocha, T. M. (2018). Effects of two commercial feeds for semi-intensive and hyper-intensive culture and four $\mathrm{C} / \mathrm{N}$ ratios on water quality and performance of Litopenaeus vannamei juveniles at high density in biofloc-based, zero-exchange outdoor tanks. Aquaculture, 490, 194-202. https://doi.org/10.1016/j.aquaculture.2018.02.028

Xu, W.-J., \& Pan, L.-Q. (2012). Effects of bioflocs on growth performance, digestive enzyme activity and body composition of juvenile Litopenaeus vannamei in zerowater exchange tanks manipulating $\mathrm{C} / \mathrm{N}$ ratio in feed. Aquaculture, 356-357, 147-152.

https://doi.org/10.1016/j.aquaculture.2012.05.022

Xu, W. J., Pan, L. Q., Sun, X. H., \& Huang, J. (2013). Effects of bioflocs on water quality, and survival, growth and digestive enzyme activities of Litopenaeus vannamei (Boone) in zero-water exchange culture tanks. Aquaculture Research, 44(7), 1093-1102. https://doi.org/10.1111/j.1365-2109.2012.03115.x

Yu, Z., Li, L., Zhu, R., Li, M., Duan, J., Wang, J.-Y., . . Wu, L.-F. (2020). Monitoring of growth, digestive enzyme activity, immune response and water quality parameters of Golden crucian carp (Carassius auratus) in zero-water exchange tanks of biofloc systems. Aquaculture Reports, 16, 100283. https://doi.org/10.1016/j.aqrep.2020.100283

Zaki, M. A. A., Alabssawy, A. N., Nour, A. E.-A. M., El Basuini, M. F., Dawood, M. A. O., Alkahtani, S., \& Abdel-Daim, M. M. (2020). The impact of stocking density and dietary carbon sources on the growth, oxidative status and stress markers of Nile tilapia (Oreochromis niloticus) reared under biofloc conditions. Aquaculture Reports, $16,100282$.

https://doi.org/10.1016/j.aqrep.2020.100282

Zhang, N., Luo, G., Tan, H., Liu, W., \& Hou, Z. (2016). Growth, digestive enzyme activity and welfare of tilapia (Oreochromis niloticus) reared in a biofloc-based system with poly- $\beta$-hydroxybutyric as a carbon source. Aquaculture, 464, 710-717.

https://doi.org/10.1016/j.aquaculture.2016.08.013 